\title{
Reducing Vulnerabilities to HIV: Does the Criminalization of HIV/AIDS Patients Contribute?
}

\author{
Yonas Mekonnen Ekubu \\ School of Law, Samara University, Samara, Ethiopia \\ Email: yonasmekonnen86@gmail.com
}

How to cite this paper: Ekubu, Y. M. (2016). Reducing Vulnerabilities to HIV: Does the Criminalization of HIV/AIDS Patients Contribute? Beijing Law Review, 7, 292-313.

http://dx.doi.org/10.4236/blr.2016.74027

Received: September 5, 2016

Accepted: November 28, 2016

Published: December 1, 2016

Copyright $\odot 2016$ by author and Scientific Research Publishing Inc. This work is licensed under the Creative Commons Attribution International License (CC BY 4.0).

http://creativecommons.org/licenses/by/4.0/

\begin{abstract}
States ever since the outbreak of HIV/AIDS have been using different methods in order to combat the pandemic if possible and to reduce vulnerability. In spite of this, HIV/AIDS continues to be prevalent especially in a less developed countries to the extent that it to be hurdle for development. Criminalization of HIV/AIDS patients is one of the mechanisms that are used in the fight against the deadly disease. However, employing criminalization as prevention and vulnerability reduction strategy poses a question and stimulates a debate. Hence, the main thrust of this article is to identify this challenge and to assess whether criminalization of HIV/AIDS patients reduce vulnerability to HIV/AIDS. This being the aim it will also go on to analyze the role of criminal law in a public health issue. In doing so, the article will discuss experience of countries in criminalization of HIV/AIDS patients along side with international frameworks. At a glance, criminal law through a vehicle of punishment seems to play a role in reducing vulnerability to HIV/AIDS but, the writer based on the analyses of relevant literature and experiences of countries, argues that the use of criminal law to address HIV is inappropriate except in rare cases where a person acts with conscious intent to transmit HIV and does so, and this is because of the high degree of proof required in criminal case and the difficulty of using criminal law in HIV related issue due to the nature of the disease and the absence of technology used for the required proof in the criminal law, i.e. beyond reasonable doubt.
\end{abstract}

\section{Keywords}

Criminalization, Transmission, Vulnerability, HIV/AIDS, Ethiopia

\section{Introduction}

HIV infection is a leading global public health issue in which no part of the globe is immune from it. Since it is known for its higher rate of reducing the human immunity 
system, adequate, effective as well as timely medical intervention is a necessary and pivotal condition. Though the fact that many scientists had tried and are still devoting their time in order to find a certain cure, their efforts remain futile for no cure has yet been discovered for HIV/AIDS, which makes the issue scarier and panic. HIV can be transmitted through different ways, the following being the major one sexual transmission where one person with an HIV infection engages in unprotected sexual intercourse with another, thus transferring the virus; blood donation and transfusions from an infected donor; the use of unsterilized needles/syringes for medical, recreational drug use, tattooing, body piercing, pregnancy and postnatal transmission. To tackle this problem, different prevention methods have been used to combat if possible, and to reduce vulnerability among HIV negative persons. Some of them had been in effective and counterproductive. Criminalization of HIV patients is one of the mechanisms being used. Criminalization of HIV patients is a focus of this paper as a mechanism to reduce HIV vulnerability. It is assumed to do so by making its focus on people who are living with HIV. Thus it will incorporate different laws and policies that aim at punishing those people who live with HIV and as well expose others to the virus. So far, states criminalize HIV transmission in two ways i.e. through applying the general criminal law, and by using HIV specific laws. As HIV is a health issue, criminalization is subject to debate. Criminalization of HIV transmission is a controversial issue and this debate constitutes to be part of this paper. And as one component, experience of countries with regard to each argument implies that there is no uniformity in criminalizing HIV.

Coming to Ethiopia, the issue of criminalization comes into picture only after the enactment of the current criminal code. Ethiopia had different forms of criminal laws, written or unwritten, codified or un codified. When the epidemics of HIV outbreaks during 1980s, the governing law was the 1957 penal code, and it has nothing to say about HIV. After 30 decades of the HIV existent, the 1957 penal code was revised, and incorporates the issue of HIV. Even here, there is no express reference, and the issue is covered by a single provision. The one and the only article relevant to this is article 514 of the current criminal code. Ethiopian courts however don't punish HIV transmission as an independent crime, as prescribed under the provision. Rather they punish individuals committing other crimes and their status of being HIV positive used as aggravating circumstance. It is a fact that Criminal law plays a role in social control through a vehicle of punishment. However when we come to criminalization of HIV patient, its contribution in reducing vulnerability of HIV transmission is a very controversial point of discussion.

The purpose of this paper is, therefore, to provide an insight on how to resolve such controversy, by assessing the contribution and effectiveness of criminalization of HIV patients to reduce vulnerability, in general and in Ethiopia.

In order to address this and other interrelated legal issues, the paper is divided into six major parts. The first part is devoted to deal with the general overview of criminalization, definition of criminalization, and the for and against argument of criminalization of HIV with respective experience of some selected countries that support each of 
the arguments on criminalization and its effectiveness or contribution. In the second part, i will deal with international legal framework and responses to criminalization, and there, what international organ and laws has said will be envisaged. The third part is allotted to deal with criminalization under Ethiopian criminal laws, and sample case of prosecution. The fourth, being the main part of the essay deals with the role of the criminalization of HIV transmission in the reduction of vulnerability, and there its contribution will be assessed both in general and in Ethiopia, and hopefully, the controversy will be resolved there. Finally, as a logical flow of all these, a concrete conclusion will be drawn.

\section{Criminalization: General Overview}

\subsection{What Is Criminalization?}

Criminalization, in criminology, is the process by which behaviors and individuals are transformed into crime and criminals ${ }^{1}$. Or in other word it can be defined as a legislation that makes something illegal ${ }^{2}$.

\subsection{Criminalization of HIV/AIDS Patients}

Criminalization of HIV patient is a phrase that is used to refer to enactment of laws directed at punishing behavior that may transmit HIV or expose others to and the application of general laws in a manner that targets those who are with HIV and may transmit or expose others to the virus ${ }^{3}$. It describes cases where the criminal law is used to prosecute people for transmitting HIV or putting another person at risk of contracting HIV. Countries around the world use different laws so as to cover the issue and to criminalize it. As a result some countries apply their criminal code while others prefer to incorporate it in a specific legislation which would be convenient to deal in depth about HIV criminalization. Most countries and their policy makers justify criminalizing HIV exposure or transmission in the retributive theory of punishment in which people that transmit HIV or expose others to the risk of HIV infection, ought to be punished because their behavior is morally wrong or harmful.

Furthermore knowing the categories of HIV transmission would be an important factor to determine the criminalization scheme. Accordingly HIV transmission can be categorized in to three. These are: intentional, reckless, and accidental transmission.

Intentional transmission or in other words deliberate or willful transmission, is the one that is made with an intended motive to transmit the virus to the other partner with or without the Knowledge of the other partner, while reckless lies on condition where the person infected with HIV act carelessly where he should act carefully, but his action is without motive to achieve the result and without the knowledge of the other partner of his status. On the other hand where a person does not know his status of

${ }^{1}$ Leadership through Accountability program: GNP+, NEP+, 2011. Global criminalization scan, Ethiopia: country assessment. Amsterdam: GNP.

${ }^{2}$ Ibid.

${ }^{3}$ ibid. 
HIV or even if he know, if he takes any caution that are necessary to prevent HIV transmission and for being unlucky HIV passed beyond his control, then it can be regarded as accidental transmission. As Described above, Classifying the transmission of HIV has an importance in determining the criminalization scheme. As a result some countries criminalize all the three ways of transmission. i.e. intentional, reckless, and accidental transmission. While some others prefer a limited way to criminalize focusing on the intentional transmission in most of the cases. In spite of these facts, criminalization of HIV patient is not as such a widely accepted idea since there are groups who strongly oppose criminalization as many as those who support the same. Thus, the following part will deal deeply on the arguments regarding criminalization.

\section{Approaches to Criminalization of HIV Patients}

The first group that support for HIV Criminalization Laws start their argument by stating the high rate of HIV prevalence around the world and the faster rate of its transmission. So that most countries legislators' urge to deter the transmission through criminalization. Moreover, they say that criminalizing HIV transmission will play an important role for achieving the deterrence rational of criminalization. Besides the monetary cost of the disease is the other rational for supporters of criminalization, they argue that states have to bear a high cost in order to fulfill the necessary medication cost. Hence, it would be better if state follows prevention principle than curing after it has happened, which would be cost effective. Furthermore proponents of criminalization approach contend that criminalization will encourage people living with HIV to take responsibility for protecting their sexual partners, unlike any other laws and policies which require the involvement of every individual for the prevention and elimination of HIV that would create difficulty to account individual. Moreover they also believe that criminalization will deter people from negative social behaviors that are highly associated with the transmission of HIV, like sex work. In addition they add its positive benefit towards vulnerable groups like women, children and others. Thus according to this approach one can conclude that criminalization of HIV transmission will play an important role for deterring the crime of HIV transmission and as well for its cost effective prevention.

Most countries in the world follow this side of the argument, and criminalize HIV transmission through their laws. At this point the Canada experience is worth mentioning as Canada is the leading country in prosecuting HIV transmission. In the jurisprudence of Canada, it is a criminal offence to transmit or expose others to the risk of infection with HIV through unprotected sex. In Canada, it is illegal for HIV-positive people to have sex without disclosing their status, in some cases even if they use a condom and even if no one gets infected. There is currently no specific section in Canada's Criminal Code making it a crime to knowingly transmit, attempt to transmit, or expose others to the risk of infection with HIV/AIDS ${ }^{4}$. However, the Supreme Court of Canada set the precedent for the criminalization of HIV exposure/transmission in 1998 with $R$

${ }^{4}$ Anne Merminod, The Deterrence Rational in the Criminalization of HIVI AIDS2(2009). 
$\mathrm{v}$ Cuerrier ${ }^{5}$. This dealt with the criminal prosecution of an HIV-positive person for engaging in sexual activity without disclosing his/her seropositive status. Overruling lower-courts decisions, the Supreme Court stated that where sexual activity poses a "significant risk of serious bodily harm", there is a duty on the HIV-positive person to disclose his or her HIV-status ${ }^{6}$.

On the other side, there are groups who oppose HIV criminalization laws, including most if not all HIV/AIDS service, lobbying, and advisory organizations and many prominent HIV scientists. They believe that these laws are counterproductive, in that they lead to the high possibility of HIV transmission. This would be the case since most laws punish people for not disclosing their status; people prefer not to know their HIV status as well as not to take any treatment including VCT. As a result it would undermine the prevention and deterrence rationales and would be the main obstacle that hinders further study on the treatment method of HIV. The other main concern of this group is the issue of stigmatization. They contend that punitive laws towards HIV transmission will promote stigma by the society since they would be perceived as harmful and this will take us back to many years in the fight against stigmatization which in turn pose a greater risk to the public.

Furthermore they argue that the requirement of disclosure of once status is an idea which goes against human rights; because they do not take in to consideration the unsupportive environment which enhances stigma and discrimination of the person living with HIV which in other words is violating human rights.

There are also some countries in the world that do not criminalize HIV transmission, and, in this discussion the experience of Mauritius is chosen. Mauritius is the only East African country to explicitly decide against criminalizing HIV exposure or transmission due to concern about detrimental impacts on public health and the conviction that it would not serve any preventive purposes like other legislation based on the AWAREHIV/AIDS model law ${ }^{7}$ A draft version of the HIV and AIDS Preventative Measures Act 2006 had originally included a provision for the prosecution of "willful" HIV transmission. Civil society engaged with parliamentarians and state-law officials who were persuaded to remove the provision after all accepting it could do more harm than good to public health and human rights ${ }^{8}$. It was said that, Criminalisation would have created more problems than solving the problems. Accordingly, Mauritius decided to put its resources where they are most likely to have a positive impact on reducing the spread of HIV: increased funding for HIV testing and counseling and for evidence-informed prevention measures ${ }^{9}$.

${ }^{5}$ Erin Dej and Jennifer M. Kilty (2012), "Criminalization Creep": A Brief Discussion of the Criminalization or HIV/AIDS Non-disclosure in Canada, 27, CANADIAN JOURNAL OF LAW AND SOCIET.55, 60(2012). ${ }^{6}$ ibid.

${ }^{7}$ Action for West Africa Region-HIV/AIDS, a model HIV criminalization law in west Africa that serve as a bench mark for countries that need to have HIV criminal law, and this trend is not unique to this region, but also available in Europe and Latin America.

${ }^{8}$ See www.criminal HIV transmission.blogspot.com.

${ }^{9}$ UNAIDS/UNDP International Consultation on the Criminalization of HIV Transmission: Summary of main issues and conclusions. Geneva, 2008. 


\section{International Legal Frame Works and Responses}

\subsection{International Legal Frameworks}

There are bulks of International instruments that have different features. Some govern relation between and among states and other stipulates obligations of states to protect rights of individual, here, human right instruments can be best example. In spite of the grave danger of HIV, the international community takes a slow movement to formulate international laws in different form concerning HIV. Due to the scope of limitation of this essay, I will only deal with international legal frame works to which Ethiopia is a party, but to date there is no single international soft or hard law dealing exclusively with criminalization issue, rather all other HIV related laws incidentally deal with it.

To start with the UN Millennium Declaration, the leaders of different states commit their nations to a new global partnership to reduce extreme poverty and setting out a series of time-bound targets, with a deadline of 2015. These targets have been translated into eight Millennium Development Goals (MDGs), which range from halving extreme poverty to halting the spread of HIV/AIDS and providing universal primary education, all by the target date of $2015^{10}$. The issue of criminalization is not raised; rather other preventive mechanisms were discussed and agreed upon.

Secondly, The Abuja Declaration sets out the commitments made by African leaders at the Abuja Summit on HIV/AIDS, Tuberculosis and Other Related Infectious Diseases, in 2001.

The Paris Declaration, which is the more developed declaration in the struggle against HIV, named AIDS as a global priority and committed signatories to ensuring that all PLWHIV ${ }^{11}$ are able to realize the full and equal enjoyment of their fundamental rights and freedoms without discrimination. The Declaration also named the Joint United Nations Programmed on HIV/AIDS, as the appropriate framework to reinforce partnerships between all involved and give guidance and worldwide leadership in the fight against AIDS.

The other and the most relevant international framework is the UN Declaration of Commitment on HIV/AIDS is an important international policy commitment made by heads of state and representatives of governments who met at the United Nations General Assembly Special Session on HIV/AIDS (UNGASS) in June 2001. The Declaration includes time-bound targets and regular reporting requirements, which serve as a powerful tool in helping to guide and secure action, commitment, support and resources for the AIDS response ${ }^{12}$.

The Three Ones, the harmonization and alignment of country-level efforts around national structures, systems and priorities were established as guiding principles for improving the country-level response during the 13th International Conference on AIDS and Sexually Transmitted Infectious in Africa (ICASA2003) held in Nairobi,

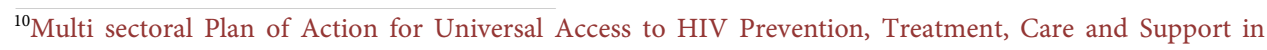
Ethiopia, p 2.

${ }^{11}$ Stands for people living with HIV/AIDS.

${ }^{12}$ Supra note 9. 
Kenya in September $2003^{13}$.

So, one can conclude that the entire above framework does not deal with criminalization at all. Besides, we can say we don't have any international legal framework relevant to the issue at hand, but, there are policy briefs made by UNAIDS, concerning criminalization, which I prefer to elucidate on the immediately upcoming part.

\subsection{International Responses}

As part of the responses in many countries, like U.S.A, Norway, and Canada, peoples especially those who live with HIV are calling repeal of such laws. In the international arena different responses are said concerning criminalization of HIV transmission. But, for this paper the responses of UNAIDS is preferred to be dealt. Firstly, it urges states to concentrate their efforts on expanding the use of proven and successful evidence, informed and rights-based public health approaches to HIV prevention, treatment and care, and limit any application of criminal law to truly blameworthy cases where it is needed to achieve justice. Secondly, the overly broad criminalization of HIV non-disclosure, exposure and transmission can be addressed in part by limiting the application of criminal law to cases of intentional transmission (i.e. where a person knows his or her HIV-positive status, acts with the intention to transmit HIV, and does in fact transmit it) ${ }^{14}$. Thirdly, punitive approaches that involve mandatory HIV testing, disclosure or treatment, or that criminalize HIV transmission, exacerbate already existing HIV stigma and discrimination and drive people away from HIV prevention and treatment into greater fear, secrecy and denial ${ }^{15}$. Fourthly, it also urges States to avoid introducing HIV-specific laws and instead apply general criminal law to cases of intentional transmission and issue guidelines to limit police and prosecutorial discretion in application of criminal law ${ }^{16}$.

Therefore, it can be concluded that UNAIDS wants states not to criminalize HIV transmission, and, to focus on other effective prevention mechanisms. But, if they are in the opinion to criminalize it, to apply only the general criminal law, and not to have HIV specific laws, and lastly, to criminalize intentional actual transmission only. So, the position of UNAIDS seems inclined to the second approach, i.e., non-criminalization of HIV transmission.

\section{Criminalization of HIV/AIDS Patients under Ethiopian Criminal Law}

Ethiopian criminal law development can be categorized in to four stages ${ }^{17}$. The stage of unwritten criminal laws, the time of fetha negest, the time of the two imperial criminal codes, and finally, the revised criminal code (the current one).

\footnotetext{
${ }^{13}$ Ibid. Accessed 7 March 2015. tion on HIV 2 (2004).

${ }^{16}$ Supra note 3 .

${ }^{17}$ Tsehay weda, Basic principles of criminal law, 4-7 (1994).
}

${ }^{14}$ UNAIDS/UNDP. Criminalization of HIV transmission Geneva, 2008. Available At:

<http://data.unaids.org/pub/BaseDocument/2008/20080731_jc1513_policy_criminalization_en.pdf >

${ }^{15}$ UNAIDS recommendations for alternative language to some problematic articles in the N'Djamena legisla- 
These all stages of criminal laws have their own prone and cons. Except, the 2004 criminal law, the rest have no any sort of relevancy with regards to criminalization of HIV, and this is for the obvious reason that HIV was nonexistent during these time. In 1980s when the epidemic of HIV becomes known to the world, it was the 1957 penal code that was in force. Having the time of its enactment in to consideration no single provision can be found dealing with HIV. Recently Ethiopia had revised its laws, and the penal law was one of the revised laws. The Revised Criminal Code, which came into force in May 2005 replacing the 1957 Penal Code, includes new provisions relevant to the HIV/AIDS pandemic. Ethiopia does not have HIV specific law ${ }^{18}$, and can be categorized to the groups that apply the general criminal law. In fact, when one go through the whole provision of the criminal code, only single article, i.e., art 514, is relevant to the issue at hand. Here, it can easily be said that Ethiopia follows the first approach to criminalization that it supports criminalization of HIV patients, which believed by putting punishments serve the purpose of punishments dealt under the criminal code. At this moment, before moving to the stated article let's see how crime itself is dealt under the code. Crime is not simply an act prohibited by law but also an act that must constitute legal, material and moral elements. It means as per the criminal $\operatorname{code}^{19} \mathrm{a}$ crime is composed of three elements i.e. legal, material and moral (mental) elements. If these three general elements are fulfilled, a person could be made liable for his /her acts or omissions. It should, however, be remembered that there are special elements in each crime that distinguish one crime from the other. But the criminal code under art 23 provides the general elements that can be used to determine whether or not an act or omission is a crime before describing the various elements in each crime. A legal element of a crime is present when a legal prescription has been infringed as a criminal law states those acts or omissions that entail liability. A crime secondly comprises a material element since criminal laws do not punish mere thoughts. A breach of the law cannot occur in the absence of given behavior and such behavior may consist of an act or omission. Finally the third element that a crime comprises is a moral or mental element. A person will be liable for a crime when he/she commits the act/omission intentionally or negligently. In other words, a person could be found guilty of a crime where he/she committed the crime while she/he was in a state of mind that is prohibited by law. Having seen what constitutes a crime under the criminal code now let's go back and see the articles that deals with the criminalization of transmission of communicable disease. Accordingly, article 514 of the criminal code criminalizes the act of a person transmitting a human communicable disease to another. The article however does not incorporate HIV clearly which makes the applicability of the article prone to various debates. Some people contend that, the article talks about communicable human diseases and it is not clear if HIV per se is a disease. The understanding at least among the scientific community is that HIV is a virus that reduces the human immunity or resistance to diseases and that may expose them to diseases rather than it being in itself a

\footnotetext{
${ }^{18}$ Here, it does not intended to say that Ethiopia has no any HIV/aids specific laws, rather, no any such specific laws that deals with criminalization of HIV transmission, but for the criminal code.

${ }^{19}$ Criminal code of the Federal democratic republic of Ethiopia, 2004, proc. No. 414, art 23.
} 
disease $^{20}$.

On the other hand, those who argue that the article deals with HIV state that it includes HIV contending that other's country experience shows HIV transmission is getting punished being treated as communicable disease. Besides, courts are punishing HIV patients for transmission using the stated article. In spite of this debate, the Ethiopian practice seems to incline to the second argument because many courts are found rendering their decision based on this article which implies the fact that courts define HIV under the category of communicable disease. Article 514 expressly criminalized the act of spreading or transmitting a communicable human disease, intentionally or negligently with varying ranges of punishment. The punishment may range from 10-20 years of rigorous imprisonment or in grave cases, imprisonment for life or death. The punishment would be simply imprisonment or fines if the act was committed negligently (Article 514(3)).

At this juncture, it would be essential to inquire as to what really constitutes intentional and negligent transmission under the criminal code? Let us see each separately:

\subsection{Intentional Transmission}

Intention is the purpose or design with which an act is done. It exists when there is a desire for the act as well as its results. It is difficult to easily determine whether a person's act or omission is intentional or not. This is because intention is a mental state which is difficult to proof its existence since it is impossible to see into somebody's mind. To solve this problem, the criminal laws of most countries put certain standards that should be followed by courts to determine whether an act or omission is intentional or not. Similarly the Ethiopian criminal code under its article 58 put elements in order to assess whether a person commit a crime intentionally or not. Consequently, a person is deemed to have committed a crime intentionally where:

He performs an unlawful and punishable act with full knowledge and intent in order to achieve a given result: or he being aware that his acts may cause illegal and punishable consequences commits the act regardless that such act may follow. The first scenario constitutes a direct intention while the second constitutes indirect intention.

Accordingly a person is assumed to commit intentionally HIV transmission if he transmit HIV with full knowledge of his HIV positive status and with a motive to achieve the result, infected other people. Or though he doesn't desire the transmission, if he accept its possible occurrence and pursues his action, it would show his indirect intention which is covered under art 58(2) of the criminal code. Besides, art 514 does not provide that attempt transmission is not punishable. Hence, in the absence of this clause, as per article 27 of the criminal code which states that an attempted crime is always punishable save as is otherwise provided by law, attempt transmission of HIV is punishable as well.

${ }^{20}$ FIKREMARKOS MERSO, Women \& Girls and HIV/AIDS in Ethiopia, 56. 


\subsection{Negligent Transmissions}

In most cases, a person is criminally liable where he commits a crime intentionally. However, in certain circumstances, he may also be criminally liable when he commits a crime negligently. A person is negligent when he does not take the care, which he is ordinarily required to take. In other words, negligence is failure in the exercise of care that should reasonably be exercised. In case of negligence, the criminal law has set standards as regards the care that should be taken and it is known as "reasonable care to prevent injury to others." The reasonable care that is expected of an individual differs from case to case. It is up to the court to decide what reasonable care is by examining the facts of the particular case at hand. So once the state of mind of fails to meet the preconditions of criminal intention as specified under article 58, then we will go on to consider if the state of mind required by the provision of article 59 is met or not. Article 59 of the criminal code introduces what is commonly known as advertent or conscious negligence and inadvertent or unconscious negligence. Advertent negligence is characterized by the fact that, although the person foresees that his act may cause harm, he believes that this harm will not occur or that the care he exercising will suffice to prevent the risk he knowingly takes from happening. The characteristics of inadvertent negligence on the oher hand are that that actor either should have or could have been aware as to the consequence of his act. It means awareness is expected from the actor under the circumstance. At this point in time I want to elucidate article 59(2) of the criminal code that states conditions for liability in case of negligence. It is notable that unlike an intentional state of mind, negligence does not always result in criminal liability. The provision of article 59(2) enumerates the conditions that should be fulfilled in order to make a person liable for his negligent conduct. Accordingly, crimes committed by negligence are liable to punishment" only if the law so expressly provides by reason of their nature, gravity or the danger they constitute to the society. Crimes by negligence are not punishable unless the law makes specific provision to this effect. This in turn is because of the gravity of the conducts or the danger it constitutes to the society at large.

As subject to the above discussion, the criminal act of HIV transmission will amount to negligence (as per art 59) if the person who is aware of his status act without care when he is required to take the necessary care and without motive to infect the other person. Failure to use condom might be a notable instance here. Besides, as well said above, crimes committed by negligence are liable to punishment only if the law so expressly provides, and art 514(3) provides to this effect stating that "Where the crime is committed negligently, the punishment shall be simple imprisonment or fine". So, under Ethiopian criminal law negligent HIV transmission is punishable.

To sum up, unlike other jurisdictions, exposure to HIV and non-disclosure of HIV status is not a crime, and only actual transmission or attempted transmission is required. Moreover, both kinds of transmissions are subject to defense. Defenses under the criminal code are dealt from art $68-81$, and are situations that reduce liability or freed from punishment depending upon the crime committed and the defense available. In most jurisdictions that criminalize HIV transmission, consent of the victim can 
be raised as a defense. It is available when the crime is done with the victims consent. But, art 70 of the Ethiopian criminal code restricts the applicability of this defense only to crimes punishable upon compliant ${ }^{21}$. Crimes are said to be upon compliant when the article stating the crime clearly mentions this fact, and as can be seen from the readings of art 514 the defense of consent in case of HIV transmission crime is worthless. Therefore, art 514 makes the availability of defense of consent nonexistent; hence, no criminal could raise the consent of the victim as sort of defense. Most states ${ }^{22}$ that criminalized HIV transmission put at least consent as defense and in this regard the Ethiopian approaches deviate and seems not fair.

Having said all this about the criminal provisions dealing with HIV transmission, now, let us see in the next heading, how the courts are prosecuting HIV transmission, which the writer believes is essential to have a wholesome in sight about criminalization in Ethiopia.

\subsection{Prosecution Cases of HIV in Ethiopian Courts: A Cursory Look at}

As one major problem in Ethiopia, the habit of recording dead cases is minimal which almost imply it's nonexistent. And those that are recorded are also difficult to find since they are not arranged based on the type of cases rather by date of their submission to the court registrar. This becomes a challenge for estimation of the reduction of transmission and the number of prosecution. And, the role of criminal law in prevention of HIV transmission cannot due to this fact be truly stated.

Thus as to the knowledge of the writer, based on the research conducted by global criminalization scan, there are four cases which relate to the issue at hand. These are $(\text { Table } 1)^{23}$.

Table 1. Criminal prosecution cases of HIV/AIDS in Ethiopia.

\begin{tabular}{|c|c|c|c|c|c|}
\hline File no. & Court & Charges & $\begin{array}{c}\text { Date of } \\
\text { prosecution }\end{array}$ & $\begin{array}{c}\text { Date of } \\
\text { conviction }\end{array}$ & Sentence \\
\hline 173,310 & $\begin{array}{l}\text { Federal first instance } \\
\text { court }\end{array}$ & $\begin{array}{l}\text { Same sex sexual act on } \\
\text { minor (defendant's } \\
\text { own son)and attempt to } \\
\text { transmit HIV }\end{array}$ & 27 March 2011 & 17 March 2011 & $\begin{array}{c}12 \text { years \& } 2 \\
\text { month }\end{array}$ \\
\hline 153,416 & $\begin{array}{l}\text { Federal first instance } \\
\text { court }\end{array}$ & $\begin{array}{l}\text { Attempt to transmit HIV to } \\
\text { sex worker by tearing the } \\
\text { condom. }\end{array}$ & 3 August 2009 & 24 June 2009 & 11 years \\
\hline 183,789 & $\begin{array}{l}\text { Federal first instance } \\
\text { court }\end{array}$ & $\begin{array}{l}\text { Same sex sexual acts on two } \\
\text { minors and attempt to } \\
\text { transmit HIV }\end{array}$ & 17 Jan. 2011 & $28 \operatorname{Jan} 2011$ & 25 years \\
\hline 22,325 & $\begin{array}{c}\text { Bahirdar city first } \\
\text { instance court }\end{array}$ & $\begin{array}{c}\text { Rape and } \\
\text { transmission of HIV }\end{array}$ & 18 Feb 2011 & 24 Feb 2011 & 15 \\
\hline
\end{tabular}

\footnotetext{
${ }^{21}$ Offences, which do not jeopardize the order, peace and security of the state and its inhabitants but are contrary solely to the rights of a given individual. These offences are of a purely private or personal character, the effect of which does not extend beyond the individual there by injured.

${ }^{22}$ United Kingdom criminal law is best example.

${ }^{23}$ Supra note 1 , at 14 .
} 
Three of the defendants in the above cases are charged with other sexual offences, however, in the course of the investigations their HIV status were revealed, and because of this they faced additional charges for HIV transmission. The occurrence of HIV transmission charges alongside with other sexual offences need to be supplemented by medical evidence. The medical evidence required includes HIV infection test. In cases where the victims of the initial sex offence is found to be HIV positive, it is not clear whether other investigation are carried out to ascertain whether indeed the alleged defendant is the source of the infection, as it is difficult to prove beyond reasonable doubt that the defendant is the actual source of the victim infection, as the source might in fact be other HIV positive person, and ascertaining it needs medical evidence in the form of phylogenetic, which is not available in Ethiopia to date (2015).

Article 514 of the criminal code implies that it is only actual transmission that is punishable, but these cases are blurring the line between actual transmission and exposure.

Without additional tests and investigations to ascertain the route and sources of the HIV infection, it appears that in the sexual assault cases above: Where the defendant is then found to be HIV positive; the only reasonable charge that can be made against them in relation to HIV is that of exposing other to the virus, which is not the case of art 514 (emphasis added) ${ }^{24}$.

As can be seen from the above cases, it can easily be said that though Ethiopia under its criminal code criminalizes HIV transmission, the un availability of medical evidences that helps to prove the required degree of criminal prove, weak court practices, confusion as to the application of the article to cases, signifies the fact that Ethiopia is not strictly speaking follows criminalization approach.

\section{Criminalization of HIV Patients' Visa Avis HIV Vulnerability Reduction}

Vulnerability is a condition of being exposed to something so easily. Whereas in our case it is a situation of being prone to HIV infection.

\subsection{Who Are Vulnerable to HIV?}

They are populations that are at higher risk of being infected or affected by HIV, who play a key role in how HIV spreads, and whose involvement is vital for an effective and sustainable response to $\mathrm{HIV}^{25}$. In every society, there are vulnerable as far as there are factors that could be reason for HIV transmission. And in particular there are individuals and population groups who are more vulnerable than others to come to harm due to their nature. Generally, the very young, the elderly and people who are sick or live with a disability are especially vulnerable in every society. In some societies, women, children, sex workers and others can also be especially vulnerable to abuse and discrimina- 
tion that would highly contribute their exposure to HIV. Now, I am going to discuss how criminalization of HIV patient contributes for the reduction of this vulnerability in the upcoming section. Criminalization of HIV could contribute to the reduction of vulnerability through direct or indirect ways. When it is direct it is to mean that by specifically criminalizing the act of transmitting HIV, whereas reducing vulnerability through criminalization of other similar acts of a criminal nature and which are mostly directed against these vulnerable groups would cover the indirect way.

\subsection{Direct Contribution of Criminalization to Vulnerability Reduction}

Criminal law plays a pivotal role in social control. It regulates anti-social behavior and gives warning not to commit crime. This role of criminal law would be visible by putting punishment. Criminal law by criminalizing HIV transmission contributes to reduction of HIV vulnerability in the following ways. These are simplya purposes of punishment and we cannot find in the criminal code a provision that states the purposes of punishment. But it can generally be grasped from the preamble and article 1 of the code.

\subsubsection{Deterrence Effect}

It is believed that the suffering that a criminal undergoes because of his punishment will deter him from engaging in a similar crime in the future, which is a specific deterrence aspect and it is also believed that it sets an example to others, to refrain from following the path of the crime, which is a general deterrence aspect. Criminalization of HIV transmission intends to teach that the crime does not pay, and the overall experience is too costly and painful to be enjoyable. Besides, it defeats recidivism by convincing through the power of the strong arm of the state that HIV transmission is not repeating. Criminalization also notifies the would be criminals about the evil consequences of the crime. In the context of HIV, an HIV-positive person contemplating consensual unprotected sex without disclosing his/her HIV status will be deterred because of the certainty that he/she will be caught and punished. The criminal penalty is supposed to have a negative inducement which will discourage people from engaging in behavior that violates the $\mathrm{law}^{26}$. So, it deter the general public not to transmit HIV, and the criminal not to do it again, and in such cases, it contributes to the reduction of vulnerability, as no one is going to transmit it, at least by fearing punishment, and let them to think twice. Especially, this would inevitably be true when there is severe punishment. Art 514 states a punishment to the range of death penalty, which certainly deters HIV positives not to infect other at least by fear of such kinds of severe punishment. Finally, Deterrence as the objective of punishment is dealt under the Ethiopian criminal $\operatorname{code}^{27}$.

\subsubsection{Incapacitation Effect}

This works by the simple mechanism of removing people who expose others from the

\footnotetext{
${ }^{26}$ Supra note 3 , at 3 .

${ }^{27}$ Supra note 19 , art 1 .
} 
population. Its value to HIV prevention depends on the extent that the law can identify people who will infect other people. So, criminalization reduces vulnerability to HIV by putting away criminals from mixing with the societies for certain period of time. This way the society spared from the disturbance created by such criminal at least to that time as, the criminal is no more with the society. So, through incapacitation, criminalization of HIV transmission at least to the period of the criminal incarnation is reduced. Putting people in prison will stop them from spreading HIV and endangering the community.

\subsubsection{Rehabilitation Effect}

Criminalization, through punishment plays a role of reforming the criminal. Those criminal that have penalized for their acts of infecting other with HIV will be reformed and be good citizen that in their later time do not try to infect other as they already recognize the evilness of their bad act. Criminal penalties for conduct that transmits or risks transmitting HIV will rehabilitate a person such that they avoid future conduct that carries the risk of HIV transmission. This in turn reduce vulnerability to HIV, as the already rehabilitated criminals are presumed to understand the wrongfulness of their previous action, and now, began to worry about to those person who are vulnerable.

\subsubsection{Retribution Effect}

HIV is a bad thing to live with, and those who made other suffer by infecting this disease should themselves suffer. People who transmit HIV or expose others to the risk of HIV infection, ought to be punished because their behavior is "morally wrong" or "harmful" 28 . Those who transmit HIV to others deserve punishment, and criminalization of HIV transmission plays this role through punishment. This role of criminal law inevitably used to reduce HIV vulnerability, in line with the above effects.

\subsubsection{Punishing Anti-Social Behavior}

Transmitting epidemic disease is anti-social behavior, and criminal law, being there to regulate anti-social behavior punishes those transmitting this disease, to keep the societies peace and order stable.

\subsection{In Direct Contribution of Criminal Law to HIV Vulnerability Reduction}

In many societies, women (taken as example from vulnerable groups $)^{29}$ have less access

\footnotetext{
${ }^{28}$ Ralf Jürgens, Jonathan Cohen, Edwin Cameron, Scott Burris, Michaela Clayton, Richard Elliott, Richard Pearshouse, Anne Gathumbi and Delme Cupido: Ten reasons to oppose the criminalization of HIV exposure or transmission, 17 REPRODUCTIVE HEALTH MATER.163,164 (2009).

${ }^{29}$ Normally, children and sex workers are also vulnerable groups, but, dealing with children will be a vast task which is beyond the scope of the essay, and as to sex workers, since they are neither legal, like the case of India, by which the government institutionalize them and levy tax, nor illegal as we see them here and there, because no law says it is illegal, and as per Ethiopian Public Health Institute, women are the highest affected in number in HIV positive status. This all are the reason why the writer chooses to discuss the issue of women only.
} 
to education and employment and they are also subjected to a range of human rights abuse which contributes to their vulnerability to HIV/AIDS. Among the problems that are faced by women, violence against women, including early marriage, sexual abuse, trafficking in person, to harmful traditional practices including FGM, abduction and rape are the most widely cited examples that increase vulnerability to HIV. Therefore criminalizing such practices would indirectly contribute for reduction of vulnerability to HIV since it would be preventing the major causes, in addition to criminalization of HIV patients.

As traditional practice early marriage increases a risk to HIV infection due to the fact that it would hinder girl's access to education, employment opportunity and to negotiate sexual relations. In addition FGM increases the risk of HIV transmission for different reasons. Firstly, the use of un-sterilized razors and knives with a possibility of HIV contamination may transmit the virus from one girl to another. Secondly, it may make the genitals more likely to tear during intercourse and thus increasing the possibility of infection. Thirdly, penetration especially in case of infibulations may probably lead to bleeding thereby facilitating transmission of the virus ${ }^{30}$. Abduction is another common practice affecting women and driving them into a marital relation without their consent and exposing them to HIV infection. The revised Criminal Code has criminalized abduction in all cases unlike the 1957 Penal Code where no proceeding could be instituted if the abducted gives her consent following the abduction. This practice allowed for negotiation by her family and the abductor-the girl being excluded from making decisions for her own affairs. Despite the revision of the Criminal Code, this practice has continued to prevail in different communities.

Therefore criminalizing such criminal acts which play a higher role in the transmission of HIV would be regarded as a tremendous effort that could be made indirectly so as to reduce vulnerability to HIV. And this seems why the current Ethiopian criminal code includes new and revised provisions relevant to the protection of women's human rights in general, and in the context of the HIV/AIDS pandemic in particular.

Accordingly, the Criminal Code addresses violence against women in different forms. The Code criminalizes most forms of violence against women and girls including rape ${ }^{31}$, trafficking women and children ${ }^{32}$, prostitution of another for gain ${ }^{33}$ and physical violence within marriage or in an irregular union ${ }^{34}$. The criminalization also extends to HTPs in general, with specific provisions on abduction ${ }^{35}, \mathrm{FGM}^{36}$, early marriage $^{37}$, and bigamy ${ }^{38}$. Furthermore, the Criminal Code has redefined the elements of some existing offences, added aggravating circumstances and revised the penalties ap-

\footnotetext{
${ }^{30}$ Fikremarkos, supra note 20 , at 40 .

${ }^{31}$ Supra note 19 , Article 620-628.

${ }^{32}$ Id. Article 597 and article 635.

${ }^{33}$ Id. Article 634.

${ }^{34}$ Id. Article 564.

${ }^{35}$ Id. Article 587-590.

${ }^{36} \mathrm{Id}$. Article 565 and article 566.

${ }^{37}$ Id. Article 649.

${ }^{38}$ Id. Article 650.
} 
plicable in cases of violation ${ }^{39}$.

Article 620 of the Criminal Code providing for rape, does not specifically refer to $\mathrm{HIV}$ as an aggravating circumstance, but one may argue that rape by a person who is HIV positive would cause grave physical or mental injury and thus such a crime shall entail life imprisonment as stated in the article. In such cases, it is also possible to charge the offender of the crimes of transmitting communicable disease and rape concurrently where the penalty could go as high as life imprisonment or death ${ }^{40}$. Therefore one can conclude that the criminal code tries to cover both aspects in order to reduce vulnerability.

As can be seen from the aforementioned discussion, criminalization of HIV transmission plays a great role to reduce HIV vulnerability. But, the application of criminal law in HIV case or criminalization of HIV transmission will have practical difficulties that reduce its effectiveness in the struggle against vulnerability reduction or HIV prevention, and these difficulties makes it to be un realistic, and paper tiger. Now, I am going to discuss the practical difficulties, in general and in Ethiopian context.

\subsection{Practical Difficulties of Criminalization of HIV Transmission}

\subsubsection{Evidence Related Problem}

Difficulty in proving that one individual actually infected another is one of the main problems that are encountered practically while dealing with HIV criminalization. There are many issues in relation to this, one being difficulty of generating proof of who infected whom? The other could relate to the cost of investigating the truth and consent or willingness of the suspect and that of the victim to take the required examination.

In relation to the first one, knowing the exact moment of sexual exposure which results the harm of HIV transmission is hardly possible. As a result it would be mandatory to know the medical history of both the accused and the compliant; this may in fact be costly but a necessary fact to serve justice. The problem may not yet be visible. However the problem comes in to picture when one cannot be sure of their HIV status before the commission of the act which exposes the victim to HIV transmission. This is a case when both the victim and the accused are not aware of their medical history of HIV status and it is difficult to bring a document which reveal previous negative or positive HIV antibody test. This greatly jeopardizes the interest of the public prosecutor in proofing the elements of a charge in the alleged crime. In criminal cases it is the public prosecutor on behalf of the government, the latter representing the public interest at large, who shoulder the burden of proof ${ }^{41}$ and in times he fails to proof the case, this will constitute as one ground for the acquittal of the accused.

${ }^{41}$ Criminal procedure code of Ethiopia, proc no.185/1961, art 136(2) and Constitution of the federal democratic republic of Ethiopia,1995, Negarit Gazzeta, extraordinary, Art 20(3). Issue, proc. No.1, year 1.also imposes burden of proof on the public prosecutor tacitly there by providing presumption of innocence for the accused.
} 
Furthermore a question may arise when an examination is required by the court as to the current status. Thus assessing whether an accused or a victim has a right to refuse examination would be an important point of discussion. Sometimes a victim may refuse to take an examination while it is mostly done by accused. For victim taking the examination is beneficial so that it is recommended if he consented to it. And the accused should also take the examination so as not to defeat a justice. Therefore it seems that the Ethiopian criminal procedure code try to comply with this idea by incorporating a compulsory HIV test in its article $34(1)^{42}$. However, a contrary position regarding physical examination is notable in civil cases ${ }^{43}$. The justification for this might be the absence of public interest in civil cases, as is dealt clearly under the civil code ${ }^{44}$. Furthermore, the Public Health Proclamation ${ }^{45}$ under art, 2(8), and 17(2) also imposes a duty on persons suspected of infection with communicable diseases to submit to testing $^{46}$. This is justified based on the claim that the result of the HIV test is essential in determining the applicable Criminal Code provision ${ }^{47}$. In addition the examination of the victim seems based on his or her consent. Moreover, the sole fact that the result shows the positive HIV status doesn't imply that the source is the accused since the complaint may have various sexual affairs or there might be some other exposure. It needs to be proven that the accused (let's call them A) was definitely the source of the accuser's (let's call them B) HIV. This would involve a range of evidence including sexual history, testing history and scientific evidence in the form of phylogenetic, as the mere fact that both are positive does not mean the source is necessarily the defendant, because the virus in both case should be the same, and this itself is not always true, as similar virus may possibly found in different person. At the same time the result of the victim being negative is not a concrete fact that $s /$ he is not infected. The difficulty here is that, the degree of prove in case of criminal cases is beyond reasonable doubt ${ }^{48}$, and this all, for sure cast a doubt. Thus this constitutes a major difficulty with regard to proof.

In order to solve the second situation courts practically wait for additional 3 month so as to ascertain the HIV status. And if the accused is positive and after the 3 month period the victim is found positive then the accused will be deemed as if he is the source

${ }^{42}$ Id. Art 34(1) sates that where an investigating police officer considers it necessary, having regard to the offence with which the accused is charged, that a physical examination of the accused should be made, he may require a registered medical practitioner to make such examination and require him to record in writing the results of such examination. Examination under this Article shall include the taking of a blood test.

${ }^{43}$ See art 20 of the Civil code of Ethiopia, 1960, Negarit Gazzeta, Extraordinary issue, proc.no.161, 19th year. ${ }^{44}$ Id., Art 20(2).

${ }^{45}$ Public health proclamation, FED. NEG. GAZETTA, art. 20 (No. 200/2000).

${ }^{46}$ Please note that neither the criminal procedure code nor the public health proclamation dealing with a mandatory physical examination does not specifically deal with HIV, but are generally referring to communicable diseases of which HIV is one.

${ }^{47}$ Supra note 19 ,Article 514 .

${ }^{48}$ This means that the proposition being presented by the government must be proven to the extent that there is no "reasonable doubt" in the mind of reasonable person that the defendant is guilty. There can still be a doubt, but only to the extent that it would not affect a "reasonable person's" belief that the defendant is guilty. If the doubt that is raised does affect a "reasonable person's" belief that the defendant is guilty, the jury(the court in our case) is not satisfied beyond a "reasonable doubt". 
of the infection. While if the result is still negative then the accused would be punished with attempted transmission of HIV.

In general it is difficult to prove whether the defendant transmits HIV to the complainant, or the complainant actually has been the source of the defendant's HIV infection. And there is no concrete evidence that exist to prove or disprove this situation.

\subsubsection{Courts Are Not Punishing HIV Transmission as a Single Crime Perse}

As seen from the above cases, HIV transmission is not independently punished, and rather courts are using it as aggravating circumstance ${ }^{49}$, which is contrary to the law that dictates it to be treated as independent crime, and, when there is another crime, it should be constituted as a concurrent crime, by which two independent charges are framed and presented to the court. But, the current trends of the courts is only relevant to the other crime and deters criminal from doing it, or the purpose of punishment will only be served to this crime, but, not to the crime of HIV transmission, and if the crime initially was rape, the being aggravated crime of HIV transmission serves to deter, or incapacitate as the case may be is to that of the rape. This in turn conveys the message that HIV transmission is not actually getting punished in it, and this hinders the intended purpose of criminalization of HIV transmission by the legislator.

\subsubsection{Human Right Concern}

As a consequence of the above problem of stigma and discrimination due to HIV criminalization laws, People living with HIV will be discriminated, and such law will hinder them from accessing their health rights, which also let the state to violate its tripartite obligation of human right, i.e., the obligation to provide adequate health standard, the obligation to protect the rights of people living with HIV not to be discriminate, and state obligation not to infringe any rights of these peoples.

\subsubsection{HIV Positive Status as a Mitigating Circumstance ${ }^{50}$}

Article 180 of the criminal code gives discretional power to courts to freely mitigate punishments. Practically, courts while punishing a criminal with certain crime other than HIV transmission mitigate a punishment if the criminal is infected with some epidemic disease that needs a serious attention, like HIV, and diabetes, provided that he can present a certificate to that effect, and courts make no punishment(it is not to mean that they go un punished, but rather, they are not sent to prison in situation of the sentence punishable with imprisonment, and be subject to parole.) in such cases the justification they state is that such diseases are very serious, and need attention. So that sending them in prison will be difficult for such criminal with such diseases to have care and protection. If this is the case, this would be difficult to have the incapacitation contribution of criminalization realistic, because, still HIV positive people would not be

\footnotetext{
${ }^{49}$ Are circumstances related to the commission of the crime indicating the degree of guilt and the dangerous disposition of the criminal, on the basis of which courts increases the penalty for particular crime committed by particular criminal.

${ }^{50} \mathrm{This}$ discussion is entirely based on the interview with Mulugata Belay, former prosecutor of MOJ, federal advocate, and producer of Chilot drama in EBC (Addis Ababa, Ethiopia, 3 December 2015).
} 
sent to prison, because of their status, and, it is not wise to say that, the mitigation is for crimes other than HIV transmission, but for HIV crimes, they would be sent to prison and for other crimes, their being HIV positive mitigate the crime and let them go home. However, this assertion is not always true, and in the time when it fails, the contribution will be realized.

\subsubsection{HIV Transmission in Prison}

The sharing of needles for injecting drugs and the high incidence of male rape and sex between men in prisons also mean that HIV transmission is still perfectly possible, even behind bars. Indeed, imprisoning a person with HIV does not prevent the transmission of HIV. HIV risk behaviors are prevalent in prison ${ }^{51}$. Moreover in country like U.S.A, where there is an adequate prison facility, it is seen that HIV is still transmitted there. And, I believe though there are no specific data in this issue yet gathered, similar problem will inevitably be happen in Ethiopia, taking shortage of prison facilities. In this point it might be said that segregation of HIV patients in prison provide a solution, but this too has a problem. On one hand, segregation foster discrimination and stigma, and this will be a violation of their right of non-discrimination. On the other hand, due to in adequate prison in Ethiopia, the doctrine of segregation will be a mere wish, as can be seen from the laws, be it national or international, that prescribed juvenile offenders should be segregated from adult offenders during their stay in prison, which is not yet practiced due to the same problem, except in Addis Ababa and, in capital cities of regions $^{52}$.

\subsubsection{Absence of Criminalization as HIV Prevention and Reduction Policy} Ethiopia's national response to the HIV/AIDS pandemic is guided by the national policy on HIV/AIDS issued in August 1998. This policy was elaborated through a five year (2000-2004) national strategic framework which was replaced by a strategic plan for the succeeding four years (2005-2008) itself supplemented by the Multi sectoral Plan of Action for Universal Access to HIV Prevention, Treatment, Care and Support in Ethiopia 2007-2010.

The priority prevention and control measures called for in the National HIV/AIDS Policy (1998) include: encourage people to maintain faithful sexual relationships with one partner; promote the use of condoms in situations where there may be the risk of HIV transmission; minimize other unsafe practices such as illegal injections, harmful traditional procedures, and drug addiction; ensure safe medical practices to protect against HIV transmission; and, ensure the human rights of people with AIDS. In referring to the implementation of the priority prevention and control measures, the policy states that people living with HIV/AIDS (herein after referred to as PLWHA), should be involved in all these efforts through education, counseling, and peer groups to help themselves live with HIV/AIDS and to communicate to the community the dangers of

\footnotetext{
${ }^{51}$ Supra note 18 , at 165 .

${ }^{52}$ See Yonas Mekonnen et al., juvenile offenders: the law and the practice, 34 (Jan. 10, 2015) (unpublished) (on file with author).
} 
risky behavior. Here, it can be immediately noticed that if PLWHA participated in the implementation of the policy, they will be aware of the risk of HIV, and began to think and save their fellow negative citizens which in turn reduce the effectiveness of criminalization. Besides, actual strategies listed for vulnerable groups in the Policy are: promote VCT and other behavioral change interventions; promote the use of male and female condoms; provide user-friendly Reproductive Health and STI services; enhance bargaining and negotiations skills for safe sex.

So, as can be seen from the above facts that the contribution of criminalization seems ignored, because it is never mentioned as a mechanism of prevention and vulnerability reduction tool and, I believe that it is deliberate due to its practical difficulties, contribution, and due to effectiveness of other models that the policy sought.

\subsubsection{Un Just Punishment}

Art 514 in grave cases impose a death penalty, and this does not seem proportional, because HIV is now ceased to be a big deal of the society, for two reason, on one hand, there become drugs that mitigate the effects of HIV, Antiretroviral drugs and it does not reduce life expectancy as such, comparing to its perception time. Individuals with HIV infection can live healthy lives and approach near normal life expectancies with access to HIV care. Early diagnosis and effective management of HIV infection not only improves clinical outcomes for infected individuals but significantly reduces their risk of transmitting the virus to others. Moreover, under modern criminal law imposing death penalty seems rejected.

\section{Concluding Remark}

Criminalization as way of HIV prevention and vulnerability reduction is being used in most countries of the world. Sates that criminalize HIV transmission justifies that the criminal should get punished for his/her evil acts, and due to the need to deter potential criminals from doing the same crime. On the other hand, those who are against the criminalization stress the fact that criminal law is hardly applicable to health issues, and the complexities of HIV hinder its effectiveness. This essay highlights these debates. International organization working on HIV is now a day's calling a repeal of such laws, or reduces the crime to intentional element only.

Ethiopia is one of the countries that criminalize HIV transmission under its criminal code in the part dealing with communicable diseases, but due to weak application of the law in the practice as witnessed from cases analyzed in the paper, and national HIV strategy and policies it will be very difficult to say that Ethiopia strictly follows criminalization approach. Application of criminal law to HIV transmission has a theoretical contribution among other things by deterring both the criminal himself and potential criminal from doing the same crime, and incapacitating the criminal not to do the crime by putting criminals away from the public. In spite of its contribution, it faces practical difficulties. As noted in the paper, criminal prosecution should be proved beyond reasonable doubt, and proofing intentional HIV transmission to such extent is 
difficult, due to the need of advanced technology which is not available in Ethiopia. Actually the difficultly faced in proofing intentional element in a crime is not only apparent for HIV related crimes, but also for other crimes, as it is a mental element which asses the state of mind of the criminal during the commission of the crime. On the top of this, I am in the opinion that intentional HIV transmission should be punished and here, the general standards set for as the precondition for the existence of intentional element should be applicable in this case too and thereby those who transmit HIV deliberately will be punished for their evil acts that presumably affects the interest of the public at large which is secured by the engagement of criminal law. As regards to intentions in HIV transmission cases, it should be ascertained that the defendant is a real source of the victim infection, and when we take this into Ethiopia current situation it will be more than difficult, due to absence of technology to acquire medical evidence that ascertains whether the accused is the real source of the victim infection. As far as vulnerability reduction is concerned, it undermines prevention efforts, basically it lets fear among people not to test HIV, and know their status for fear of prosecution for non disclosure of their status.

Criminalization of HIV transmission is now a day's becoming in effective, as HIV itself is left being a big deal. Seemingly, to this effect, countries in the world are repealing their laws. I believe that the contribution of criminalization of HIV transmission is not realistic on the ground, as it go against to its purported purpose, and counterproductive. Concerning art 514 of the criminal code I am in the opinion that it should be made crime only to intentional transmission, and be re crafted in such away, as criminalizing unintentional transmission of HIV by punitive laws and policies may have an adverse effect on the lives of people living with HIV and will serve no purpose since to reduce vulnerability is not conceivable by punishing those people who do not even know that their acts are wrong. If conclusion has to be made regarding to the question that is raised under the introductory part of this paper that inquires whether criminalization of HIV patients contribute to vulnerability of HIV, based on the forgoing discussion, I may say yes, it contribute, as it putts punishment, that serves different purposes to reduce HIV vulnerability on one or another way. But, I also say that it is not effective owning to practical difficulties discussed under the paper. And, concerning its effectiveness it would be effective, had there not been any difficulties. Therefore, the practical difficulties render it to be ineffective in contributing for the reduction of vulnerabilities to HIV.

Based on the above conclusion the following can be said, as a matter of recommendation. As regards to the government, awareness creation should be escalated and encouragement via different means should be under taken in order people to get tested and know their status. Protection to people living with HIV should be accorded more than ever, and provision of adequate material should also be given to them. Though it appears to be a long way to go, technology that enables for prove of HIV infection of the victim by the defendant should be made available to effectively punish intentional HIV transmission, and thereby incorporate criminalization as a prevention mechanism 
under its HIV AIDS strategy and policy. Besides, discrimination and stigma should be avoided to the extent possible. Eventually, the legislator should reconsider art 514 in a way that only punishes intentional transmission and, death penalty as punishment should be avoided. And it should also come up with laws concerning vulnerable groups to HIV, In order to make vulnerable groups part of the prevention effort.

\section{References}

Civil Code of Ethiopia (1960). Negarit Gazzeta, Extraordinary Issue, Proc. No. 161, 19th Year.

Constitution of the Federal Democratic Republic of Ethiopia (1995). Negarit Gazzeta, Extraordinary Issue, Proc. No. 1, Year 1.

Criminal Code of the Federal Democratic Republic of Ethiopia (2004). Negarit Gazzeta, Extraordinary Issue, Proc. No. 414, 19th Year.

Criminal Procedure Code of Ethiopia (1961). Negarit Gazzeta, Extraordinary Issue, Proc. No. 185,19 th Year.

Dej, E., \& Kilty, J. M. (2013). Criminalization Creep": A Brief Discussion of the Criminalization of HIV/AIDS Non-Disclosure in Canada. Canadian Journal of Law and Society, 27, 55-66. http://dx.doi.org/10.3138/cjls.27.1.055

Merminod, A. (2009). The Deterrence Rational in the Criminalization of HIV/AIDS. Lex Electronica, 13, 4-28.

Merso, F. (2007). Women \& Girls and HIV/AIDS in Ethiopia: An Assessment of the Policy and Legal Framework Protecting the Rights of Women and Girls and Reducing Their Vulnerability to HIV/AIDS.

Multi Sectoral Plan of Action for Universal Access to HIV Prevention, Treatment, Care and Support in Ethiopia.

Public Health Proclamation (2000). Negarit Gazzeta, Extra Ordinary Issue, Proc. No. 200, 6th Year.

Ralf, J. et al. (2009). Ten Reasons to Oppose the Criminalization of HIV Exposure or Transmission. Reproductive Health Matters, 17, 163-172.

Tsehay Weda, Basic Principles of Criminal Law (1994).

UNAIDS Recommendations for Alternative Language to Some Problematic Articles in the N’Djamena Legislation on HIV (2004).

UNAIDS/UNDP International Consultation on the Criminalization of HIV Transmission: Summary of Main Issues and Conclusions. Geneva, 2008. 
Submit or recommend next manuscript to SCIRP and we will provide best service for you:

Accepting pre-submission inquiries through Email, Facebook, LinkedIn, Twitter, etc. A wide selection of journals (inclusive of 9 subjects, more than 200 journals)

Providing 24-hour high-quality service

User-friendly online submission system

Fair and swift peer-review system

Efficient typesetting and proofreading procedure

Display of the result of downloads and visits, as well as the number of cited articles

Maximum dissemination of your research work

Submit your manuscript at: http://papersubmission.scirp.org/

Or contact blr@scirp.org 